\title{
Assessment of Potential of Bio-Agents on Root Knot Nematode Meloidogyne incognita in Bhendi
}

\author{
T. Senthilkumar*, S. Vinothini and M. Kalaivani \\ Department of Plant Protection, Anbil Dharmalingam Agricultural College \& Research \\ Institute, Tiruchirappalli-620027, Tamil Nadu, India \\ *Corresponding author
}

\begin{tabular}{|c|}
\hline Keywords \\
\hline $\begin{array}{l}\text { Pseudomonas } \\
\text { fluorescens, Verticillium } \\
\text { chlamydosporium, } \\
\text { Meloidogyne incognita, } \\
\text { Bhendi, Liquid } \\
\text { formulation }\end{array}$ \\
\hline Article Info \\
\hline $\begin{array}{l}\text { Accepted: } \\
15 \text { July } 2018 \\
\text { Available Online: } \\
10 \text { August } 2018\end{array}$ \\
\hline
\end{tabular}

\section{Introduction}

Nematodes are roundworms that occupy a vast array of ecological niches and have many different lifestyles. Of more than 1.7 million species of nematodes on earth, only a handful are known to feed on plants. The species of greatest concern to vegetable growers is the root knot nematode Meloidogyne incognita (Kofoid \& White) Chitwood. Root-knot nematode is so named as it causes characteristic knots on roots of the hosts.
Among the vegetable crops Bhendi, Abelmoschus esculentus (L.) is an important crop grown extensively under various agroclimatic zones of India is adversely affected by the root-knot nematode, $M$. incognita. Estimated yield losses of up to $90 \%$ have been recorded under field conditions, depending upon initial soil nematode population densities (Bhatti and Jain, 1977; Jain and Gupta, 1986). The external symptom on the aerial part of affected plant includes dwarfing, foliar discoloration, wilting and premature death of 
the plants. However, the external manifestation of the symptoms depends on severity of nematode infection. Even though application of nematicides for the control of root-knot nematodes has been found effective, nowadays use of bio-agents is encouraged due to economical and eco-friendly method of nematode management. Use of beneficial microorganism as talc formulation is explored extensively for the management of nematode population in various crops. Hence, present study was undertaken to compare and evaluate the commercially available liquid formulation of bio-agents for the management of root knot nematode $M$. incognita infecting bhendi.

\section{Materials and Methods}

Pot culture experiment was conducted at Department of Plant Protection, Anbil Dharmalingam Argricultural College and Research Institute, Trichy to study the bio control potential on root knot nematode management using commercially available liquid formulation of Pseudomonas fluorescens, Paecilomyces lilacinus, Verticillium chlamydosporium. Bacillus subtilis and Trichoderma viride with standard check $P$. fluorescens $\left(P f_{1}\right)$ (talc formulation) along with chemical check Carbofuran $3 \mathrm{G}$ and compared with untreated control.

Sowing of bhendi var. COBhH-1 seeds were done in the pots (containing $5 \mathrm{~kg}$ pot mixture) arranged in a Completely Randomized Design (CRD) under shade net. Root knot nematode culture was maintained at culture pots with tomato seedlings, since tomato seedling is highly susceptible to root knot nematode. Root galls from the culture pot plants were collected and examined under microscope to isolate the egg masses; then they were placed in petri dish containing water and kept for hatching. Freshly hatched root knot nematode juveniles were collected and inoculated at the rate of $1 \mathrm{~J}_{2} / \mathrm{g}$ of soil in the pots one week after germination of bhendi seeds. Followed by application of biocontrol agents as soil drenching as per the treatment schedule with three replication viz., P. fluorescens $(2 \mathrm{ml} / \mathrm{L})$, P. lilacinus $(2 \mathrm{ml} / \mathrm{L}), T$. viride $(2 \mathrm{ml} / \mathrm{L}), V$. chlamydosporium $(2 \mathrm{ml} / \mathrm{L})$, B. subtilis $(2 \mathrm{ml} / \mathrm{L})$, Carbofuron $3 \mathrm{G}$ (1 $\mathrm{kg}$ a.i./ha), with standard check $P$. fluorescens (Pf1) (2g/L) and untreated control. The experiment was terminated 90 days after treatment in Bhendi. Yield data were recorded every harvest and plant growth parameters were recorded at the time of termination. Rhizosphere soil and root samples were collected and examined for nematode population. The collected data were recorded and analysed using statistical software AGRESS.

\section{Results and Discussion}

All the data were analyzed and tabulated. From table 1 it was observed that all the biocontrol agents showed efficacy on plant growth parameters and nematode population reduction in soil as well as root when compared to untreated control. The maximum shoot length and shoot weight of bhendi was recorded $60.79 \%$ and $54.87 \%$ respectively in the plants treated with $P$. fluorescens $(2 \mathrm{ml} / \mathrm{L})$ followed by $V$. chlamydosporium $(2 \mathrm{ml} / \mathrm{L})$ compared with untreated control. Similarly $P$. fluorescens $(2 \mathrm{ml} / \mathrm{L})$ treated plants were recorded root length and root weight of $50 \%$ and $45 \%$ respectively which was higher than that of untreated control.

Regarding yield of bhendi $P$. fluorescens $(2 \mathrm{ml} / \mathrm{l})$ treated plants yielded maximum of $0.19 \mathrm{~kg} /$ plant compared to other treatments. Though the number of fruits (14) per plant were more in $T$. viride $(2 \mathrm{ml} / \mathrm{L})$ and $V$. chlamydosporium $(2 \mathrm{ml} / \mathrm{L})$ treated plants but the weight of fruits was low $(0.16 \mathrm{~kg}$ per plant). $P$. fluorescens $(2 \mathrm{ml} / \mathrm{L})$ yielded 12 fruits with greater size, hence the weight was increased compared to other treatment (Table $2)$. 
Table.1 Study on potential of bio control agents on plant growth parameters in bhendi

\begin{tabular}{|c|c|c|c|c|c|c|}
\hline TREATMENT & $\begin{array}{c}\text { Shot } \\
\text { length } \\
\text { (cm) }\end{array}$ & $\begin{array}{l}\text { Shoot } \\
\text { weight } \\
\text { (g) }\end{array}$ & $\begin{array}{l}\text { Root } \\
\text { length } \\
(\mathrm{cm})\end{array}$ & $\begin{array}{c}\text { Root } \\
\text { weight } \\
\text { (g) }\end{array}$ & $\begin{array}{l}\text { No. of } \\
\text { fruits/ } \\
\text { plant }\end{array}$ & $\begin{array}{c}\text { Fruit } \\
\text { weight/ } \\
\text { plant (kg) }\end{array}$ \\
\hline T1 - P. fluorescens (2ml/L) & 44.7 & 30.2 & 7.5 & 6.1 & 12 & 0.19 \\
\hline $\mathrm{T} 2-$ P. lilacinus $(2 \mathrm{ml} / \mathrm{L})$ & 39.0 & 23.3 & 6.0 & 5.3 & 11 & 0.15 \\
\hline $\mathrm{T} 3-T$. viride $(2 \mathrm{ml} / \mathrm{L})$ & 37.4 & 24.7 & 6.3 & 5.1 & 14 & 0.16 \\
\hline $\mathrm{T} 4-$ V. chlamydosporium $(2 \mathrm{ml} / \mathrm{L})$ & 40.8 & 29.2 & 7.2 & 5.6 & 14 & 0.16 \\
\hline T5 - B. subtilus (2ml/L) & 41.3 & 24.3 & 6.3 & 4.9 & 13 & 0.16 \\
\hline T6 - Carbofuran 3G (1kg a.i./ha) & 36.5 & 25.1 & 5.6 & 4.8 & 12 & 0.17 \\
\hline T7 - P. fluorescens (Pf1) (2g/L) & 41.3 & 27.2 & 7.4 & 5.3 & 13 & 0.18 \\
\hline T8 - untreated control & 27.8 & 19.5 & 5.0 & 4.2 & 10 & 0.11 \\
\hline CD (5\%) & 3.4007 & 5.9700 & 0.8271 & 0.9254 & 3.9185 & 0.0158 \\
\hline SEd & 1.6042 & 2.8161 & 0.3902 & 0.4365 & 1.8484 & 0.0075 \\
\hline
\end{tabular}

Table.2 Study on effect of bio control agents on root knot nematode Meloidogyne incognita in bhendi

\begin{tabular}{|c|c|c|c|c|}
\hline TREATMENT & $\begin{array}{l}\text { Nematode } \\
\text { population } \\
\text { (250g soil) }\end{array}$ & $\begin{array}{c}\text { Female Adult } \\
\text { nematode } / 1 \mathrm{~g} \\
\text { root }\end{array}$ & $\begin{array}{l}\text { Number of } \\
\text { Egg mass/1g } \\
\text { root }\end{array}$ & $\begin{array}{l}\text { Root gall } \\
\text { index }\end{array}$ \\
\hline $\mathrm{T} 1$ - P. fluorescens $(2 \mathrm{ml} / \mathrm{L})$ & 151 & 12 & 7 & 2 \\
\hline $\mathrm{T} 2-P$. lilacinus $(2 \mathrm{ml} / \mathrm{L})$ & 167 & 13 & 6 & 3 \\
\hline $\mathrm{T} 3$ - T. viride $(2 \mathrm{ml} / \mathrm{L})$ & 207 & 17 & 8 & 4 \\
\hline T4 - V. chlamydosporium $(2 \mathrm{ml} / \mathrm{L})$ & 152 & 12 & 4 & 2 \\
\hline T5 - B. subtilus (2ml/L) & 179 & 14 & 7 & 4 \\
\hline T6 - Carbofuran 3G (1kg a.i./ha) & 147 & 10 & 3 & 1 \\
\hline T7 - P. fluorescens (Pf1) (2g/L) & 171 & 13 & 6 & 3 \\
\hline T8 - untreated control & 268 & 19 & 10 & 5 \\
\hline $\mathrm{CD}(5 \%)$ & 18.9316 & 3.4073 & 2.9980 & \\
\hline SEd & 8.9203 & 1.6073 & 1.4142 & \\
\hline
\end{tabular}

Lowest number of root knot nematode population (151) was recorded in $P$. fluorescens $(2 \mathrm{ml} / \mathrm{L})$ treated plant followed by $V$. chlamydosporium $(2 \mathrm{ml} / \mathrm{L})$. The adult female nematode population was also recorded as 12 per $g$ of root in $P$. fluorescens $(2 \mathrm{ml} / \mathrm{L})$ and $V$. chlamydosporium $(2 \mathrm{ml} / \mathrm{L})$ treated plants respectively. Number of egg mass per $\mathrm{g}$ of root was lowest in $V$. chlamydosporium ( $2 \mathrm{ml} / \mathrm{L})$ compared to untreated control. Lowest root gall index 2 was recorded in P. fluorescens $(2 \mathrm{ml} / \mathrm{L})$ and $V$. chlamydosporium (2ml/L) compared to untreated control (5).

From this experiment it is observed that all the liquid formulation of bio-control agents was effectively reduced the $M$. incognita population in soil as well as root. Suppression of root knot nematode population by $P$. fluorescens was due to its nematicidal action (Keuken and Sikora, 1995) and alteration of 
root exudates, which affect the hatching and mortality of juveniles (Oostendorp and Sikora, 1990) finally nematode population were reduced simultaneously increase the plant growth significantly (Santhi and Sivakumar, 1995). Liquid formulation of this beneficial bacterium was suited for both seed as well as soil application (drenching) results rapid and aggressive root colonization. It is evidenced with the findings of Senthilkumar et al., (2011), the population of M. incogntia and Radopholus similis significantly reduced in soil with the application of that PGPR consortium in black pepper. In this study it is observed that the liquid formulation have the bio-control potential on nematode management when compared with the talc formulation (Vetrivel et al., 2010). From this research experiment it is concluded that use of bio-control agents as liquid formulation effectively inhibit the nematode population and increase the plant growth positively. Hence it may be recommended to the farmers for the management of root knot nematode effectively and obtain more yield.

\section{References}

Bhatti D.S and Jain R.K., 1977. Estimation of loss in okra, tomato and brinjal yield due to Meloidogyne incognita. Indian Journal of Nematology, 7: 37-41.

Jain R.K and Gupta D.C., 1986. A note on the screening of some chemicals as seed treatment for control of root-knot nematode (Meloidogyne javanica) infesting okra. Haryana. Journal of Horticulture Science, 15: 288-290.

Keuken, O. and R.A. Sikora. 1995. Biological control of root knot nematode, Meloidogyne incognita with the rhizosphere bacteria Bacillus subtitles and bacterial production of toxic metabolites. Nematologica, 41: 315.

Oostendorp, M and R.A. Sikora. 1990. In vitro interrelationships between rhizosphere bacteria and Heterodera schachtii. Revue de Nematologie, 13: 269-274.

Santhi, A. and C.V. Sivakumar. 1995. Biocontrol Potential of Pseudomonas fluorescens (Migula) against root knot nematode, Meloidogyne incognita (kofoid and white, 1919) chitwood, 1949 on tomato. Journal of Biological control, 9: 113-115.

Senthilkumar, T., M. Ananthan and E. I. Jonathan. 2011. Field experiment on efficacy of Pseudomonas fluorescens (Pfbv 22) and Bacillus subtilis (Bbv57) on Meloidogyne incognita and Radopholus similis in black pepper, National Symposium on "Nematodes: A Challenge Under Changing Climate and Agricultural Practices" 16th-18th Nov., 2011, Kovalam, Thiruvananthapuram, Kerela, 89 PP.

Vetrivel. P, Sivakumar. M, and Jonathan. E.I. 2010. Biocontrol potential of endophytic bacteria on Meloidogyne incognita and its effect on plant growth in bhendi. Journal of Biopesticides. Vol. 3(2): 452-457

\section{How to cite this article:}

Senthilkumar, T., S. Vinothini and Kalaivani, M. 2018. Assessment of Potential of Bio-Agents on Root Knot Nematode Meloidogyne incognita in Bhendi. Int.J.Curr.Microbiol.App.Sci. 7(08): 2528-2531. doi: https://doi.org/10.20546/ijcmas.2018.708.257 